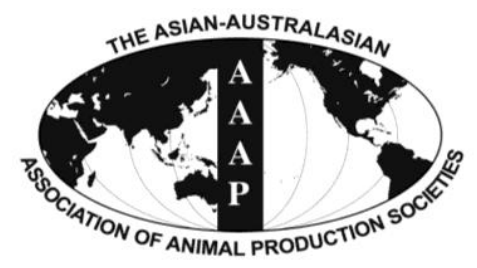

Asian Australas. J. Anim. Sci.

Vol. 26, No. 11 : 1630-1636 November 2013

http://dx.doi.org/10.5713/ajas.2013.13160

www.ajas.info

pISSN 1011-2367 elSSN 1976-5517

\title{
Carcass Characteristics and Qualitative Attributes of Pork from Immunocastrated Animals
}

\author{
Fabiana Ribeiro Caldara*, Marta Moi, Luan Sousa dos Santos, Ibiara Correia de Lima Almeida Paz, \\ Rodrigo Garófallo Garcia, Irenilza de Alencar Nääs, and Alexandre Rodrigo Mendes Fernandes \\ Federal University of Grande Dourados, College of Agrarian Sciences, Dourados, MS, Brazil
}

\begin{abstract}
An investigation was carried out to assess the carcass characteristics and meat quality aspects of immunocastrated male pigs of medium genetic potential for lean meat deposition in carcass (53 to 55\%). When the crossbred Large White $\mathrm{x}$ Landrace pigs ( $\mathrm{n}=$ 45) were 70 days old, they were distributed in a totally randomized design in three treatments (castrated males, females and immunocastrated males) with three replicates of five animals. The pigs were slaughtered when they were 140 days old. Carcass temperature and $\mathrm{pH}$ were recorded twice, at $45 \mathrm{~min}$ and $24 \mathrm{~h}$ after slaughter. The carcasses were evaluated for hot and cold carcass yield, commercial cuts yield, length and depth, back fat thickness, loin eye area and lean meat percentage. The Longissimus dorsi muscle was extracted for analysis of color ( $\left.\mathrm{L}^{*}, \mathrm{a}^{*}, \mathrm{~b}^{*}\right)$, exudate loss, cooking loss and centesimal and sensorial analysis of the meat. There were no significant differences for the evaluated parameters between castrated males, immunocastrated males and females, except for backfat thickness between the 7th and 8th thoracic vertebra and the point P2 (lower for immunocastrated males) and carcass temperature at 45 min post slaughter (higher in immunocastrated males), however, this did not interfer with the rate of $\mathrm{pH}$ decrease post mortem and the meat quality. The results from this research did not indicate a benefit of immunocastration on carcass characteristics of pigs of medium genetic potential for lean meat deposition in carcass, when compared to surgical castration. (Key Words: Backfat Thickness, Immunocastration, Lean Meat, Water Holding Capacity)
\end{abstract}

\section{INTRODUCTION}

In today's swine production, a large part of the slaughtered herd is of castrated males. The gonadectomy in young pigs is a usual practice in swine production worldwide. It is estimated that near 100 million piglets are castrated annually just in the European Union (Thun et al., 2006). However, castrated males present reduced feed efficiency and nitrogen retention and also less lean meat to fat (Pauly et al., 2009), which makes the production more expensive when compared to non-castrated males. Another significant aspect is that surgical castration decreases a piglets production performance (Prunier et al., 2006). As castration is a painful and stressing procedure it has been abolished in some countries (Bauer et al., 2008). These negative aspects of the surgery procedure have influenced its gradual abandonment; however, the carcass odor of noncastrated pigs remains an issue.

\footnotetext{
* Corresponding Author: Fabiana Ribeiro Caldara. Tel: +55-6781188114, E-mail: fabianacaldara@ufgd.edu.br Submitted Mar. 19, 2013; Accepted Jul. 3, 2013; Revised Jul. 16, 2013
}

It is clear that alternatives to the surgical castration of pigs must be used, but they need to be practical, economically feasible, do not cause adverse impacts to animal performance and meet consumer requirements and principles of animal welfare. The immunological castration using anti-GnRH is a procedure which can replace surgical castration of male pigs, as it has proved effective in reducing the concentration of the main hormones responsible for causing the carcass odor (Dunshea et al., 2001). It also allows the animals to have longer satisfactory performance and carcass characteristics than those of noncastrated males, generating positive productive impact on the pig production. Its application, however, should be studied with care, as there are issues related to the economic viability and consumer acceptance of pork from treated pigs. Many studies support the effectiveness of this management; which is used in animals of high genetic potential (pigs of commercial lines genetically improved, with potential for lean meat deposition in carcass greater than 56\%) (Pauly et al., 2009; Gispert et al., 2010; Skrlep et al., 2010). However, these benefits are not automatically extended to pigs with lower performance. 
This research aimed to study the effects of immunocastration of pigs of medium genetic potential in the parameters of carcass and meat quality.

\section{MATERIAL AND METHODS}

\section{Local, experimental design, diets and animals management}

The study was conducted at the Swine Experimental Sector, Federal University of Grande Dourados, Agrarian Sciences College, MS, Brazil. A total of 45 Landracex Large White crossbred pigs were used. They were 70 days old, and with an average weight of $25.2 \pm 2.8 \mathrm{~kg}$, consisting of 15 females and 30 males that were distributed in a fully randomized experimental design with three treatments, three repetitions with 15 pigs per treatment. The treatments were T1 (females), T2 (surgically castrated males), and T3 (immunocastrated males). All pigs were in the same rearing conditions, in open sided pens with semi-automated feeders and nipple drinkers, concrete floor, and a herd density of 0.8 $\mathrm{m}^{2} /$ animal.

The trial period was $70 \mathrm{~d}$, divided into two phases growing (70 to110 d) and finishing (111 to $140 \mathrm{~d}$ ). The experimental fodder was formulated using corn and soybean and supplemented with minerals and vitamins (Rostagno et al., 2011). The management requirements for boars during growth and females in the finishing phase were met. Fodder and water were provided ad libitum throughout the trial.

The castrated animals were subjected to orchiectomy procedure on the seventh day of life. Immunocastrated animals received two dosages of Vivax, which is a vaccine based on a synthetic analogue of GnRH coupled to a large carrier protein. It was applied subcutaneous and the first dosage was given at $60 \mathrm{~d}$ before slaughter (pigs were 80 days old) while the following at 30 days before slaughter (pigs were 110 days old).

\section{Carcass quality measurements}

At the end of the experimental period, the animals were put on a fast from solid feed for $18 \mathrm{~h}$; they were then weighted and slaughtered and their performance and carcass characteristics and meat quality were evaluated. Immediately after stunning by electronarcosis, the animals were bled via jugular incision and subjected to scalding, eviscerated and divided into two half-carcasses. At $45 \mathrm{~min}$ after slaughter $\mathrm{pH}$ and temperature of carcasses were recorded using $\mathrm{pH}$ meter coupled to a penetration probe, inserted into the center of the Longissimus dorsi muscle in the left half-carcass between the 12th and 13th thoracic vertebra. The procedure was repeated $24 \mathrm{~h}$ after slaughter.

The carcasses were weighed in order to obtain the hot carcass weight $(\mathrm{HCW})$. The carcass was considered with the head, tail and feet. It was chilled in the refrigerator for $24 \mathrm{~h}$ at $\pm 2{ }^{\circ} \mathrm{C}$ temperature, and re-weighed to determine the weight of the cooled carcass (CCW). Carcass yield (\%) was calculated by the carcass weight (hot and cold) $\times 100$, divided by the live weight at slaughter as described by Bridi and Silva (2007). The length and depth of carcasses were recorded using the Brazilian method for carcass classifying (BMCC). The backfat thickness between the 7th and 8th thoracic vertebra, between the 3rd and 4th lumbar vertebra, and at the point $\mathrm{P} 2$ was measured using calipers. The loin eye area was recorded according to the methodology proposed by Boggs and Merkel (1993), which consisted of the section between the 10th and 11th ribs of the left half carcass, where a cross section of the Longissimus dorsi was exposed. A decal was made using transparent plastic in order to get the shape of that muscle. The determination of the area was done with the aid of a plastic matrix formed by a square with an area of $0.25 \mathrm{~cm}^{2}$. The left half was dissected into primary cuts (ham with bone and without skin, shoulder boneless and skinless, rack and blade shoulder) for determining the yield of each cut (weight of the component in relation to the chilled carcass weight $x$ 100). The lean meat yield was calculated as the ratio between the weight of lean meat (ham with bone, blade shoulder, boneless shoulder and boneless rack) and the standard carcass (half carcass weight minus the weight of the head, feet, tail and lard) as suggested by Rose (2001).

\section{Meat quality measurements}

The qualitative measurements in the Longissimus dorsi muscle were done using the methodologies described as follows:

Meat color: aiming the muscle oxygenation each sample remained exposed to the air for $15 \mathrm{~min}$. After this period, the meat was slightly dried with paper towels and the color was measured using a portable color meter (Minolta CR 410). The components $\mathrm{L}^{*}$ (lightness), $\mathrm{a}^{*}$ (red-green) and $\mathrm{b}^{*}$ (yellow-blue) were shown in the color system CIELAB and assessed at three different points of the muscle surface using illuminant D65 and observational angle of $10^{\circ}$.

Exudate loss (EL): samples in steak form of $2.5 \mathrm{~cm}$ width were prepared and the external fat removed, and weighted in a semi-analytic scale. They were kept as a simulated retail sale on a $45^{\circ}$ angle of inclination shelf, in trays covered with a plastic film at $4 \pm 1^{\circ} \mathrm{C}$ during $48 \mathrm{~h}$. After this period, the exudate was discharged, and the samples were weighted again. The EL was expressed as a percentage of the initial weight.

Weight loss by cooking (WLC): samples in steak form of $2.5 \mathrm{~cm}$ width were prepared and the external fat was removed and weighed in a semi-analytic scale, and roasted without the addition of condiments. The oven was preheated to the temperature of $170^{\circ} \mathrm{C}$. The internal 
temperature of the samples was monitored during cooking using sensors tied to a digital thermometer. When samples' internal temperature reached $80^{\circ} \mathrm{C}$ they were taken from oven and cooled at room temperature, and then they were weighted. WLC was expressed in percentage of water lost in relation to the original sample weight.

Shear force $(S F)$ : three cylinder sub-samples were removed from each WLC sample, parallel to the muscle fiber orientation. Sub-samples were placed with the fiber oriented perpendicular to the Warner-Bratzler lamina as described by Froning et al. (1978). The average of three repetitions and the value of shear force for each sub-sample were used for assessing the tenderness of the meat.

Sensorial analysis: samples in steak form of $2.5 \mathrm{~cm}$ width were roasted without the addition of condiments in a pre-heated oven at the temperature of $170^{\circ} \mathrm{C}$ until the internal temperature reached $80^{\circ} \mathrm{C}$. Sensory evaluations were performed for meat tenderness, juiciness, flavor and odor, based on a nine-point scale, using a non-trained panel of forty tasters, according to Kauffman et al. (1993). Later on with the same testers' team the Triangle Test (ABNT, 1993) was performed in which, in each round of tests three samples of meat were served concurrently to the tester, being two equal and one different. The testers were asked to try the samples and mark the different sample in question regarding flavor. Testers were asked their opinion of intent to buy and preference in relation to the evaluated products.

Proximate analysis: five samples of each treatment were lyophilized for determining the amount of dry matter. After the assessment of the moisture, the samples were used for determining the raw protein content, ether extract and mineral matter (BRASIL, 1981).

\section{Statistical analysis}

ANOVA was applied to mean values using the SAS 9.2 computer package (SAS, 2001), applying the general linear model (GLM). Means were compared using Tukey test considering $5 \%$ level of significance, when test $\mathrm{F}$ was significant for all variables. For the pork sensorial characteristics, the Kruskal-Wallis test was applied as suggested by Sampaio (2002).

\section{RESULTS AND DISCUSSION}

The carcass $\mathrm{pH}$ at $45 \mathrm{~min}$ and $24 \mathrm{~h}$ after slaughter did not differ between treatments. However, immunocastrated pigs presented a higher carcass temperature at $45 \mathrm{~min}$ after slaughter (Table 1). After $24 \mathrm{~h}$ of slaughter castrated pigs presented a higher carcass temperature that may have been related to a thicker subcutaneous fat which served as a thermal isolation retaining the carcass cooling.

There was no evidence of the presence of PSE meat since it presents a $\mathrm{pH}$ value of less than 5.8 at 45 min post
Table 1. Temperature and $\mathrm{pH}$ of the carcass of castrated male pigs, immunocastrated, and females at $45 \mathrm{~min}$ and $24 \mathrm{~h}$ post mortem

\begin{tabular}{lccc}
\hline \multirow{2}{*}{ Variable } & \multicolumn{3}{c}{ Treatment } \\
\cline { 2 - 4 } & Castrated & Female & Immunocastrated \\
\hline $\mathrm{pH} 45 \mathrm{~min}$ & 6.15 & 6.04 & 6.01 \\
$\mathrm{pH} 24 \mathrm{~h}$ & 5.60 & 5.71 & 5.61 \\
$\mathrm{~T}^{\circ} \mathrm{C} 45 \mathrm{~min}$ & $29.77^{\mathrm{b}}$ & $30.54^{\mathrm{b}}$ & $32.22^{\mathrm{a}}$ \\
$\mathrm{T}^{\circ} \mathrm{C} 24 \mathrm{~h}$ & $7.45^{\mathrm{a}}$ & $5.80^{\mathrm{b}}$ & $6.15^{\mathrm{b}}$ \\
\hline
\end{tabular}

Means followed by different letters in the line differ between them by Tukey test $(\mathrm{p}<0.05)$.

mortem (Velazco, 2001). Although immunocastrated males had higher carcass temperature at $45 \mathrm{~min}$ (about two degrees higher), no association was found between this parameter and accelerated reduction in $\mathrm{pH}$. The final $\mathrm{pH}$ is within the range considered normal for pork.

Comparing the quality of meat from castrated males, females and immunocastrated Pauly et al. (2009) and Gyspert et al. (2010) observed no differences in relation to the initial and final $\mathrm{pH}$ between different types of pork and the values found by these researchers were close to those obtained in the present experiment. No difference was found $(p>0.05)$ in carcass yield hot or cold, loss during cooling, depth and carcass length, loin eye area, lean meat yield and backfat thickness between the 3rd and 4th lumbar vertebra, between carcasses of pigs immunocastrated, castrated and females. Surgically castrated males had higher backfat thickness between the 7 th and 8 th thoracic vertebra than females and immunocastrated. Immunologically castrated males presented lower backfat thickness at the point P2 than females and males castrated; however, the amount was not sufficient to provide different percentages of lean meat (Table 2).

When evaluating pig carcass characteristics from different genetic groups Guimarães (2007) did not find a difference in hot and cold carcass or in loss to cooling between females and castrated males. Assessing carcass parameters of immunocastrated pigs Moraes et al. (2010) identified the effect of sex on the hot carcass yield, and the females showed higher yield than the immunocastrated pigs; which were superior to castrated males. However, Pauly et al. (2009) found larger values of carcass yield for castrated males $(79.5 \%)$ than those of immunocastrated (78.3\%), values similar to those observed in the present study. Lanferdini et al. (2012) also found cold carcass yield almost 3\% higher for surgically castrated males than immunocastrated pigs. According to Rosa et al. (2008) carcass yield may be influenced by age and weight at slaughter. It is higher for females, in the finishing phase I than to castrated males while the opposite occurs in the finishing phase II.

Guimarães et al. (2011) found no difference between barrows and gilts of commercial lines for BT between the 
Table 2. Hot carcass yield (HCY), cold carcass yield (CCY), cooling loss (CL), loin eye area (LEA), backfat thickness between the 7th and 8th thoracic vertebra (BT $\times 7$ and 8 ), backfat thickness between the 3rd and 4th lumbar vertebra (BT $\times 3$ and 4$)$, backfat thickness at point P2 (BT P2), lean meat yield (LMY), length and depth of carcass from male immunocastrated, surgical castrated and female pigs

\begin{tabular}{|c|c|c|c|c|}
\hline \multirow{2}{*}{ Variable } & \multicolumn{3}{|c|}{ Treatment } & \multirow{2}{*}{$\mathrm{CV}(\%)$} \\
\hline & Castrated & Female & Immunocastrated & \\
\hline $\mathrm{HCY}(\%)$ & 79.85 & 81.37 & 80.64 & 6.20 \\
\hline $\operatorname{CCY}(\%)$ & 77.98 & 79.45 & 78.67 & 4.73 \\
\hline CL $(\%)$ & 2.35 & 2.36 & 2.44 & 13.47 \\
\hline $\operatorname{LEA}\left(\mathrm{cm}^{2}\right)$ & 35.46 & 34.33 & 37.74 & 14.28 \\
\hline $\mathrm{BT} \times 7$ and $8(\mathrm{~mm})$ & $26.32^{\mathrm{a}}$ & $24.05^{\mathrm{b}}$ & $23.29^{\mathrm{b}}$ & 23.70 \\
\hline $\mathrm{BT} \times 3$ and $4(\mathrm{~mm})$ & 18.31 & 17.91 & 17.56 & 26.74 \\
\hline BT P2 (mm) & $14.09^{\mathrm{a}}$ & $14.73^{\mathrm{a}}$ & $11.16^{\mathrm{b}}$ & 19.77 \\
\hline LMY (\%) & 53.29 & 53.17 & 54.82 & 4.40 \\
\hline Depth (cm) & 31.30 & 31.70 & 32.40 & 5.76 \\
\hline Length $(\mathrm{cm})$ & 76.70 & 77.90 & 75.70 & 3.64 \\
\hline
\end{tabular}

Means followed by different letters in the line differ between them by Tukey test $(\mathrm{p}<0.05)$.

10th and 11th rib, BT in P2 and LEA. The backfat thickness values found by these authors were similar to those found in the present study. These LEA values were higher than those determined by this study. Although that research had pigs with a different slaughter weight $( \pm 109 \mathrm{~kg}$ compared to this study which used pigs of $\pm 90 \mathrm{~kg}$ ), which may have been due to the low genetic potential of crossbred Large Whitex Landrace when compared to animals of commercial strains.

When comparing carcass characteristics of male and immunocastrated pigs Tonietti (2008) observed that the immunocastrated pigs presented higher hot carcass weight, larger amount of meat and lean percentage, greater loin eye area and lower amount of fat than those non-castrated animals. Pauly et al. (2009) also found higher yield of lean meat in immunocastrated males $(56.3 \%)$ than in castrated males $(54.5 \%)$, values that were similar to those found in the present study. In contrast, McCauley et al. (2003) reported greater fat deposition in immunocastrated animals than in non-castrated pigs.

No difference was found in the cuts yield from all treatments ( $p>0.05$; Table 3$)$. Assessing the commercial cuts in pig carcasses, Guimarães (2007) noted that females presented higher means for ham yield than castrated males, suggesting that the carcass of sows should be used in the market due to their large cuts yield. Comparing the commercial cuts between male pigs and immunocastrated

Table 3. Yield (\%) of commercial cuts of male immunocastrated, surgical castrated and female pigs

\begin{tabular}{lrrrr}
\hline \multirow{3}{*}{ Cut } & \multicolumn{3}{c}{ Treatment } & \\
\cline { 2 - 4 } & Castrated & Female & $\begin{array}{c}\text { Immuno- } \\
\text { castrated }\end{array}$ & \\
\hline Ham & 22.87 & 21.99 & 23.28 & 4.71 \\
Shoulder & 10.38 & 10.13 & 11.12 & 9.11 \\
Rack & 13.12 & 14.70 & 13.52 & 6.84 \\
Blade shoulder & 6.92 & 6.35 & 6.91 & 8.81 \\
\hline
\end{tabular}

Lanferdini et al. (2012) found a higher yield of rack in surgically castrated pigs than non-castrated pigs, and greater weight and ham yield for immunocastrated pigs than for non-castrated ones. Tonietti (2008) and Pauly et al. (2009) results suggest that immune castration improved the performance of pigs in relation to males surgically castrated, and also added more meat cuts with higher commercial value, such as ham, rack, belly and shoulder, suggesting that this may represent economic benefit for the meat industry.

No difference was found in the loss by cooking between the meat of gilt (24.57\%), surgical castrated male $(26.73 \%)$ and immunocastrated pigs $(23.65 \%)$ (Figure 1). The values found were close to those obtained by Bridi et al. (2006). Pork from castrated pigs presented higher exudate loss $(7.32 \%)$ than gilts $(3.54 \%)$ and immunocastrated pigs (Figure 1). The values of exudate loss from pork of the pigs surgically castrated were higher than that reported by Lien et al. (2002) and Kuo and Chu (2003) for regular meat (1.6\% and $4.51 \%$, respectively). Loss of exudate occurs as a

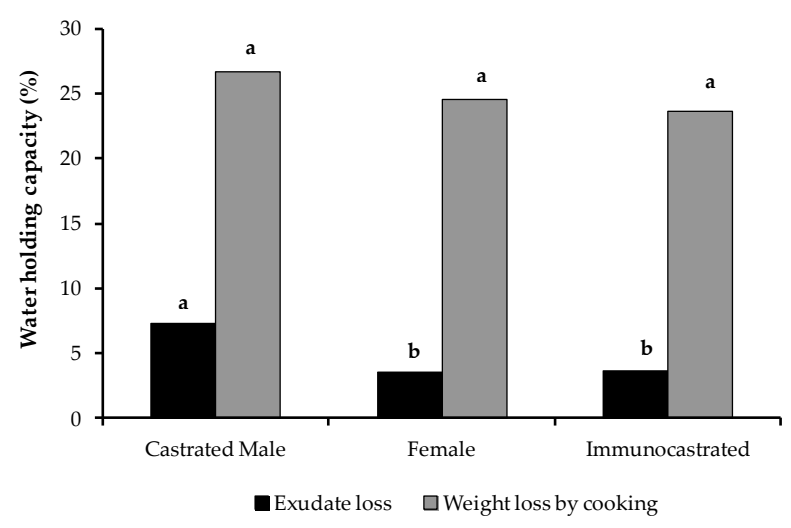

Figure 1. Exudate loss (\%) and weight loss by cooking (\%) of loin of male immunocastrated, surgical castrated and female pigs. Means followed by different letters in the line differ between them by Tukey test $(\mathrm{p} \leq 0.05)$. 
consequence of the shrinking of the myofibrils in the period post mortem, and it is one of the main factors of quality loss in meat products (Jensen et al., 2003). After the cut of the carcass, the exudate contributes to the total loss of water, and it is influenced by the decline of the $\mathrm{pH}$, the size of the pieces and the time of processing.

The loss by cooking is due to the shrinking of the myofibrils during the process, and it can vary through time and cooking temperature since high temperatures may cause denaturation of proteins, subcutaneous, intramuscular and inter muscular fat loss. Although current literature (Cronin et al., 2003) indicates that immunocastrated pigs may have their backup of glycogen used quicker than non-castrated pigs, affecting changes in the $\mathrm{pH}$ during the conversion of muscle in meat, therefore, affecting pork quality; this was not observed in the present study.

No difference was found $(p>0.05)$ in the values of redness $\left(a^{*}\right)$ and yellowness $\left(b^{*}\right)$ in the meat of male immunocastrated, surgical castrated and female pigs. Shear force did not differ between the tested pigs. Surgically castrated males presented meat with higher lightness than immunocastrated ones (Table 4).

The quality of pork and its presentation to the consumer may be affected by several factors. A genetic selection for production of lean meat has resulted in changes, in physical characteristics and muscle metabolism, influencing the visual and organoleptic characteristics of pork and hence the acceptability of the product by consumers. The lightness in color of the meat can be affected by the amount of water present in it. Meats that have reduced water holding capacity reflect light in a dispersed way, making it lighter than normal meat. This could explain the fact that the meat from castrated animals appears paler since its water retention capacity was significantly lower than the other pigs. The American Meat Science Association (America Meat Science Association, 2001) considers the $\mathrm{L}^{*}$ values between 49 and 60 within the normal standards of pork quality and the values found in the present study were normal despite the treatments. However, Ramos and Gomide (2007) consider the $\mathrm{L}^{*}$ values of normal meat to be in the range between 45 and 53 .

Table 4. Lightness $\left(\mathrm{L}^{*}\right)$, redness $\left(\mathrm{a}^{*}\right)$, yellowness $\left(\mathrm{a}^{*}\right)$ and shear force (SF) of the muscle longissimus dorsi of male immunocastrated, surgical castrated and female pigs

\begin{tabular}{lcccc}
\hline \multirow{2}{*}{ Variable } & \multicolumn{3}{c}{ Treatment } & CV (\%) \\
\cline { 2 - 4 } & Castrated & Female & $\begin{array}{c}\text { Immuno- } \\
\text { castrated }\end{array}$ \\
\hline $\mathrm{a}^{*}$ & 13.47 & 13.75 & 14.24 & 5.06 \\
$\mathrm{~b}^{*}$ & 7.79 & 7.03 & 6.87 & 9.88 \\
$\mathrm{~L}^{*}$ & $60.45^{\mathrm{a}}$ & $58.93^{\mathrm{ab}}$ & $57.29^{\mathrm{b}}$ & 4.63 \\
$\mathrm{SF}(\mathrm{kgf})$ & 3.63 & 3.61 & 4.17 & 18.66 \\
\hline
\end{tabular}

Means followed by different letters in the line differ between them by Tukey test $(\mathrm{p}<0.05)$.
Table 5. Humidity, crude protein (CP), mineral matter (MM) and ether extract (EE) of the meat of male immunocastrated, surgical castrated and female pigs

\begin{tabular}{lrrcr}
\hline \multirow{2}{*}{ Variable } & \multicolumn{3}{c}{ Treatment } & \\
\cline { 2 - 4 } & Castrated & Female & $\begin{array}{c}\text { Immuno- } \\
\text { castrated }\end{array}$ \\
\hline Humidity & 80.40 & 80.50 & 79.88 & 0.86 \\
CP & 14.75 & 14.34 & 14.65 & 3.68 \\
MM & 1.11 & 1.08 & 1.06 & 7.18 \\
EE & 3.63 & 3.98 & 4.28 & 20.30 \\
\hline
\end{tabular}

Results expressed in the wet weight basis.

Pauly et al. (2009) found no differences in relation to lightness, redness and yellowness when comparing the quality of meat from surgically castrated, non-castrated, and immunocastrated pigs. However, $\mathrm{L} *$ values observed by the authors (50.1 to 51.0) were lower than those obtained in the present study. The same authors found that meat from surgically castrated and non-castrated males was more resistant to cut than the meat from immunocastrated meat. A plausible cause for this difference may be the compensatory growth of immunocastrated pigs compared to surgically castrated and non-castrated pigs at the end of the finishing period, followed by an increased proteolytic capacity (reason: calpain:calpastatin) and a high rate of softening. The SF values obtained by these authors were similar to those observed in the present study (3.45 to 3.77 ). The results of the shear force for the loins of the three treatments may be considered suitable for softness with pork. According to Iversen et al. (1995) the threshold between the softness and hardness of pork, measured through the SF is $6.0 \mathrm{kgf}$.

The centesimal composition of meat from immunocastrated pigs was not different from that of barrows and gilts ( $\mathrm{p}>0.05$; Table 5).

Meat odor, visual appearance, tenderness, juiciness and flavor, did not differ (Table 6) between the flesh of animals castrated, immunocastrated and females. On a 7-point hedonic scale, the odor was rated between "liked moderately" and "genuinely liked". As for the visual appearance, tenderness, juiciness and flavor answers were mostly between "not liked/disliked" or "liked moderately". There was no difference in the opinion of "purchase intent"

Table 6. Sensorial parameters and intention of purchase pork from male immunocastrated, surgical castrated and female pigs

\begin{tabular}{lccc}
\hline \multirow{2}{*}{ Variable } & \multicolumn{3}{c}{ Treatment } \\
\cline { 2 - 4 } & Castrated & Female & Immunocastrated \\
\hline Odor & 5.23 & 5.64 & 5.29 \\
Visual aspect & 4.68 & 4.64 & 4.83 \\
Softness & 5.08 & 5.26 & 4.90 \\
Juiciness & 4.78 & 4.82 & 4.54 \\
Flavor & 4.87 & 5.09 & 4.67 \\
Intention of purchase & 2.56 & 2.22 & 2.35 \\
\hline
\end{tabular}


that was placed on a 5-point scale between "probably buy" and "maybe/maybe not".

The Triangular test, when three coded samples were given to testers, being two equal (female and surgically castrated male) and one different (immunocastrated pig), the testers were not able to identify the pork from the immunocastrated pig.

Skrlep et al. (2010) found that pigs surgically castrated presented with less frequency and intensity of displeasing odor than of those from immunocastrated pigs. Conversely, it was found that meat from boars presented strong disagreeable odor (92\%). Only two samples of pork from immunocastrated pigs were identified as having a strong "boar taint", despite the fact that the samples from the immunocastrated pigs presented lower androsterone level than the limit detected in laboratory. The efficacy of immunocastration for preventing boar odor in meat has been proved by the reduction of hormone levels (Dunshea et al., 2001; Metz et al., 2002; Turkstra et al., 2002; Jaros et al., 2005; Schmoll et al., 2009), by sensorial study done with consumers (Font I Furnols et al., 2008) as well as by panel testers (Pearce et al., 2008; Font I Furnols et al., 2009).

\section{IMPLICATIONS}

Immunocastration can replace surgical castration without change to the qualitative characteristics of the meat. However, the benefits towards the improvement of the carcass are not as promising as in animals with high genetic potential, and immunocastration should be evaluated on its economic feasibility in swine production systems that use animals with low growth potential and carcass meat deposition.

\section{ACKNOWLEDGEMENTS}

The work was supported by the Mato Grosso do Sul State Foundation for the Development of Teaching, Science and Technology (FUNDECT), Brazil.

\section{REFERENCES}

ABNT (Associação Brasileira De Normas Técnicas) 1993. Teste triangular em análise sensorial dos alimentos e bebidas - NBR 12995. São Paulo: ABNT, 1993. 5p

AMSA (American Meat Science Association) 2001. Meat Evaluation Handbook, American Meat Science Association, Savoy, IL.

Bauer, A., M. Lacorn, K. Danowski, and R. Claus. 2008. Effects of immunization against GnRH on gonadotropins, the GH-IGF-Iaxis and metabolic parameters in barrows. Animal 2:12151222.

Boggs, D. L. and A. R. Merkel. 1993. Live animal carcass evaluation and selection manual. 4th ed. Dubuque: Kendal/Hunt Pub. Co.

Bonneau, M. and W. J. Enright. 1995. Immunocastration in cattle and pigs. Livest. Prod. Sci. 42:193-200.

BRASIL. Ministério da Agricultura. Secretaria Nacional de Defesa Agropecuária. Laboratório Nacional de Referência Animal. 1981. Portaria n. 001/81, de 07 de outubro de 1981. Métodos analíticos oficiais para controle de produtos de origem animal e seus ingredientes. I. Métodos microbiológicos. II. Métodos físicoquímicos. Brasília.

Bridi, A. M. and C. A. Silva. 2007. Métodos de Avaliação da Carcaça e da Carne Suína. 1th ed. Londrina: MIDIOGRAF, v.1. Bridi, A. M., A. R. Oliveira, N. A. N. Fonseca, M. Shimokomaki, L. L. Coutinho, and C. A. Silva. 2006. Efeito do genótipo halotano, da ractopamina e do sexo do animal na qualidade da carne suína. Rev. Bras. Zootec. 35:2027-2033.

Cronin, G., F. R. Dunshea, K. L. Butler, I. Mcauley, J. L Barnett, and P. H. Hemsworth. 2003. The effects of immuno- and surgical-castration on the behaviour and consequently growth of group-housed, male finisher pigs. Appl. Anim. Behav. Sci. 81:111-126.

Dunshea, F. R., C. Colantoni, K. Howard, I. McCauley, P. Jackson, K. A. Long, S. Lopaticki, E. A. Nugent, J. A. Simons, J. Walker, and D. P. Hennessy. 2001. Vaccination of boards with a GnRH vaccine (Improvac) eliminates boar taint and increases growth performance. J. Anim. Sci. 79:2524-2535.

Font I Furnols, M., M. Gispert, L. Guerrero, A. Velarde, J. Tibau, J. Soler, M. Hortós, J. A. García-Regueir, J. Pérez, P. Suárez, and M. A. Oliver. 2008. Consumer's sensory acceptability of pork from immunocastrated male pigs. Meat Sci. 80:1013-1018.

Font I Furnols, M., J. Gonzalez, M. Gispert, M. A. Oliver, M. Hortós, J. Pérez, P. Suárez, and L. Guerrero. 2009. Sensory characterization of meat from pigs vaccinated against gonadotropin releasing factor compared to meat from surgically castrated, entire male and female pigs. Meat Sci. 83:438-442.

Froning, G. W., A. S. Babji, and F. B. Mather. 1978. The effect of preslaughter temperature, stress, stuggle and anesthetization on color and textural characteristics of turkey muscle. Poult. Sci. 57:630-633.

Guimarães, G. G. 2007. Desempenho e características de carcaça suína de dois cruzamentos de linhagens comerciais criados em cama sobreposta. PhD. Thesis, Universidade de Brasília, Faculdade de Agronomia e Medicina Veterinária, Brasília, DF, Brazil .

Guimarães, G. G., L. S. Murata, C. Mcmanus, A. P. Santana, G. C. Reckziegel, A. S. Amâncio, R. M. J. Filho, and A. J. F. Sobrinho. 2011. Desempenho de suínos de dois cruzamentos de linhagens comerciais criados em cama sobreposta. Arch. Zootec. 60:11-18.

Gyspert, M., M. A. Oliver, A. Velarde, P. Suarez, J. Peréz, and M. Font I Furnols. 2010. Carcass and meat quality characteristics of immunocastrated male, surgically castrated male, entire male and female pigs. Meat Sci. 85:664-670.

Iversen, P., P. Henckel, L. M. Larsen, S. Monllao, and A. J. Moller. 1995. Tenderization of pork as affected by degree of coldinduced shortening. Meat Sci. 40:171-181.

Jaros, P., E. Bürgi, K. D. C. Stärk, R. Claus, D. Hennessy, and R. Thun. 2005. Effect of active immunization against GnRH on 
androstenone concentration, growth performance and carcass quality in intact male pigs. Livest. Prod. Sci. 92:31-38.

Jensen, J. M., C. Prestat, K. J. Ryan, K. L. Robbins, C. L. HomcoRyan, F. Mckeith, and M. S. Brewer. 2003. Enhancement solution effects on shelf-life, color and sensory characteristics of pork chops during retail display. J. Food Qual. 26:271-283.

Kauffman, R. G., R. L. Van Laack, R. L. Russell, E. Pospiec, C. A. Cornelius, .C. E. Suckow, and M. L. Grease. 1998. Can pale, soft, exudative pork be prevented by postmortem sodium bicarbonate injection? J. Anim. Sci. 76:3010-3015.

Kuo, C. C. and C. Y. Chu. 2003. Quality characteristics of Chinese sausages made from PSE pork. Meat Sci. 64:441-449.

Lanferdini, E., P. A. Lovatto, R. Melchior, C. C. Klein, J. Broch, and G. G. Garcia. 2012. Características de carcaça e da carne de suínos machos castrados e imunocastrados alimentados com diferentes níveis nutricionais. Ciência Rural 42:2071-2077.

Lien, R., M. C. Hunt, S. Anderson, D. H. Kropf, T. M. Loughin, M. E. Dikeman, and J. Velazco. 2002. Effects of endpoint temperature on the internal color of pork patties of different myoglobin form, initial cooking state, and quality. J. Food Sci. 67:1011-1015.

Mccauley, I., M. Watt, D. Suster, D. J. Kerton, W. T. Oliver, R. J. Harrell, and F. R. Dunshea. 2003. A GnRF vaccine (Improvac ${ }^{\circledR}$ ) and porcine somatotropin (Reporcin $\AA$ ) have synergistic effects upon growth performance in both boars and gilts. Aust. J. Agric. Res. 54:11-20.

Metz, C., K. Hohl, S. Waidelich, S. W. Drochner, and R. Claus. 2002. Active immunization of boars against GnRH at an early age: consequences for testicular function, boar taint accumulation and N-retention. Livest. Prod. Sci. 74:147-157.

Pauly, C., P. Spring, J. V. O'doherty, S. Ampuero Kragten, and G. Bee. 2009. Growth performance, carcass characteristics and meat quality of group-penned surgically castrated, immunocastrated (Improvac $($ ) and entire male pigs and individually penned entire male pigs. Animal 3:1057-1066.

Pearce, M. C., A. Baker, S. I. Hughes, G. R. Nute, F. M. Wittington, and J. D. Wood. 2008. Eating quality of pork loin steaks from light slaughter weight boars vaccinated with Improvac. In: EAAP, Girona, Spain, 26-27 March.

Prunier, A., M. Bonneau, E. H. Von Borell, S. Cinotti, M. Gunn, B. Fredriksen, M. Giersing, D. B. Morton, F. A. M. Tuyttens, and A. Velarde. 2006. A review of the welfare consequences of surgical castration in piglets and evaluation of non-surgical methods. Anim. Welfare 15:277-289.

Ramos, E. M. and L. A. M. Gomide. 2007. Avaliação da qualidade de carnes: Fundamentos e Metodologias. Viçosa, MG, Ed. UFV.
Rosa, A. F., P. J. A. Sobral, C. G. Lima, and J. D. F. Gomes. 2001. Determinação das características físico-químicas da carne de suínos em fase de crescimento. Rev. Tec. Carnes, Campinas, SP, 3:13-18.

Rosa, A. F., J. D. F. Gomes, M. R. Martelli, P. J. A. Sobral, and C. G. Lima. 2008. Qualidade da carne de suínos de três linhagens genéticas comerciais em diferentes pesos de abate. Ciência Rural 38:1394-1401.

Rostagno, H. S., L. F. T. Albino, J. L. Donzele, P. C. Gomes, R. F. Oliveira, D. C. Lopes, A. S. Ferreira, S. L. T. Barreto, and R. F. Euclides. 2011. Tabelas Brasileiras para aves e suínos. Composição de alimentos e exigências nutricionais. $3^{\mathrm{a}} \mathrm{Ed}$. Viçosa, MG: Universidade Federal de Viçosa.

Sampaio, I. B. M. 2002. Estatística aplicada à experimentação animal. 2.ed. Belo Horizonte: FEPMVZ.

SAS Institute Inc. 2001. SAS/STAT user's guide: Version 6. 6th ed. SAS Institute Inc., Cary, North Carolina.

Schmoll, F., J. Kauffold, A. Pfutzner, J. Baumgartner, F. Brock, M. Grodzycki, and S. Andrews. 2009. Growth performance and carcass traits of boars raised in germany and either surgically castrated of vaccinated against gonadotropin-releasing hormone. J. Swine Health Prod. 17:250-255.

Škrlep, M., B. Šegula, M. Prevolnik, A. Kirbiš, G. Fazarinc, and M. Čandek - Potokar. 2010. Effect of immunocastration (Improvac $\left.{ }^{\circledR}\right)$ in fattening pigs II: Carcass traits and meat quality. Slov. Vet. Res. 47:65-72.

Thun, R., Z. Gajewski, and F. F. Janett. 2006. Castration in male pigs: techniques and animal welfare issues. J. Physiol. Pharmacol. 57:189-194.

Tonietti, A. P. 2009. Avaliações do desempenho zootécnico, qualidade da carcaça e carne em suíno macho inteiro imunocastrado. Ph.D. Thesis, Universidade de São Paulo, Escola Superior de Agricultura Luiz de Queiroz, Piracicaba, SP, Brazil.

Turkstra, J. A., X. Y. Zeng, J. T. H. M. Van Diepen, A. W. Jongbloed, H. B. Oonk, D. F. van de Wielt, and R. H. Meloen. 2002. Performance of male pigs immunized against GnRH is related to the time of onset of biological response. J. Anim. Sci. 80:2953-2959.

Velazco, J. 2001. Prevención de PSE en carne de cerdo. Rev. Carne Tec. 8:28-34

Zeng, X. Y., J. A. Turkstra, A. W. Jongbloed, J. T. van Diepen, R. H Meloen, H. B Oonk, D. Z Guo, and D. F. M van de Wiel. 2002. Performance and hormone levels of immunocastrated, surgically castrated and intact male pigs fed ad libitum highand low- energy diets. Livest. Prod. Sci. 77:1-11. 